\title{
Urszula MarkowsKa-Manista
}

Katedra UNESCO im. Janusza Korczaka, Interdyscyplinarnych Studiów nad Rozwojem i Dobrostanem Dziecka

E-MAIL: umarkow@wp.pl

\section{DOMINIKA ZAKRZEWSKA-OLĘDZKA}

Wydział Stosowanych Nauk Społecznych, Akademia Pedagogiki Specjalnej w Warszawie E-MAIL: dzakrzewska@aps.edu.pl

\section{Pomiędzy teorią a praktyką kontaktu międzykulturowego}

\section{Wprowadzenie}

We współczesnym zglobalizowanym świecie, w którym $\mathrm{z}$ jednej strony można obserwować otwarcie granic (liczne przykłady współpracy międzynarodowej, tworzenia koalicji pomiędzy krajami, między innymi: Unia Europejska, NATO, EOG, Grupa Wyszehradzka czy Unia Afrykańska), z drugiej zaś nasilającą się radykalizację młodzieży oraz tendencje nacjonalistyczne i fundamentalistyczne w społeczeństwach europejskich i pozaeuropejskich, kontakt międzykulturowy stanowi podstawę wspólnotowego funkcjonowania społeczności, grup i jednostek. Tadeusz Lewowicki pisze, że

państwa i społeczeństwa Unii Europejskiej nie są wolne od konfliktów narodowościowych, etnicznych, kulturowych. Wciąż ujawniają się postawy ksenofobiczne, szowinistyczne, wrogie wobec Innych. Dżin źle pojmowanego patriotyzmu, nacjonalizmu w najgorszym wydaniu, został wypuszczony i krąży wśród ludzi. Różne czynniki (m.in. kryzysy gospodarcze, sytuacja na rynku pracy, ale też odradzające się fundamentalizmy światopoglądowe, ambicje polityków) sprawiają, że społeczeństwa UE przeżywają kłopoty kojarzone z wielokulturowością [Lewowicki, 2015: 15].

W owej wielokulturowej przestrzeni ustawicznych kontaktów ujawniające się różnice są bodźcem uruchamiającym negatywne stereotypy i uprzedzenia, skutkując odrzuceniem, wykluczeniem, zamknięciem i/lub agresją. Te same różnice (w sprzyjających warunkach i/lub na skutek odpowiedniego przygotowania uczestników interakcji) 
motywują do wzajemnego poznawania się, ustawicznego negocjowania, dają szansę przechodzenia od reakcji na odmienność, gdzie często występuje brak zrozumienia, megalomania, ksenofobie, uprzedzenie bazowanie na stereotypach, do interakcji, czyli celowego poznawania, zrozumienia, współpracy, współdziałania, negocjacji, ustawicznego dialogu rozumianego jako imperatyw rozwoju i zachowania pokoju [Nikitorowicz, 2013: 19].

Wielowymiarowość i wielopłaszczyznowość interakcji, redefiniowania siebie i innych w kontakcie międzykulturowym, w dobie współczesnych zintensyfikowanych ruchów migracyjnych, ma tak pozytywny, jak i negatywny wydźwięk społeczny, kulturowy czy polityczny. Każdy z uczestników interakcji - jak pisze Krystyna Błeszyńska -

spostrzega i interpretuje doświadczaną sytuację oraz jej poszczególne składowe (rodzaj i charakter sytuacji, cele i normy interakcji, role poszczególnych uczestników, symbole, skrypty i kody komunikacyjne) przyjmując jako punkt odniesienia przede wszystkim własną kulturę, oczekiwania i doświadczenia. Przyjmowane w trakcie interakcji cele, perspektywy i skrypty komunikacyjne poszczególnych partnerów mogą się przy tym różnić, zwiększając znaczenie podejmowanych uzgodnień i negocjacji [Błeszyńska, 2013: 2].

Stąd, aby możliwe było tworzenie koalicji i współpracy pomiędzy krajami, społecznościami czy grupami o zróżnicowanym pochodzeniu kulturowym lub wyznaniowym, niezbędne jest wzajemne poszanowanie, zrozumienie zasad współpracy, wola wejścia w interakcję i porozumiewanie się językiem zrozumiałym dla wszystkich stron dialogu a więc międzykulturowe komunikowanie się.

\section{Wokół teorii kontaktu i komunikacji międzykulturowej}

\section{Zdaniem Jerzego Nikitorowicza}

komunikacja międzykulturowa zakłada już w samej swej etymologii istnienie odmiennych kulturowo grup, zauważanie i poznawanie się, porozumienie i współpracę, jak też zdążanie do wypracowania paradygmatu współistnienia [Nikitorowicz, 2011: 19]. 
Proces ten ściśle jest związany z możliwością nabywania kompetencji międzykulturowych, które w literaturze przedmiotu definiowane są między innymi jako

umiejętność rozpoznawania różnic i podobieństw pomiędzy określoną kulturą a własną” oraz jako „umiejętność odpowiedniego zachowania podczas spotkań z przedstawicielami obcych kultur [Bem, 2013: 127].

Za kolejny poziom rozwoju kompetencji międzykulturowych uznawane są kompetencje wielokulturowe [Bem, 2013], które mówią już nie tylko o świadomości tożsamości kulturowej jednostki, ale również o posiadaniu przez nią praktycznej umiejętności zgodnego, efektywnego współżycia w jednym społeczeństwie z przedstawicielami innych kultur. Kompetencje międzykulturowe decydują więc o adaptacji do nowych, zmieniających się warunków kulturowych i społecznych, o wchodzeniu w relacje interpersonalne $\mathrm{z}$ osobami o zróżnicowanym pochodzeniu kulturowym oraz mogą przyczynić się do rozwiązywania napięć i konfliktów o podłożu kulturowym.

Czynnikami umożliwiającymi nabywanie zarówno kompetencji międzykulturowych, jak i wielokulturowych jest otwarcie na różnorodność i docenianie jej, umiejętność oceny siebie w kontekście kultury, posiadanie odpowiedniego poziomu wiedzy, umiejętności zrozumienia wartości podobieństw oraz różnic i odpowiedniego zachowania się z szacunkiem dla nich oraz świadomość dynamiki procesów zachodzących podczas interakcji z innymi. Kompetencje te mogą zostać nabyte i rozwinięte przede wszystkim w wyniku aktywnego uczestnictwa w kontakcie z przedstawicielami odmiennych kultur i własnego doświadczenia.

Natomiast czynnikami utrudniającymi nabywanie kompetencji międzyi wielokulturowych oraz nawiązywanie kontaktu są kształtowane w trakcie socjalizacji uprzedzenia i stereotypy. Stanowią one istotny czynnik w utrzymywaniu relacji społecznych, gdyż leżą u podstaw międzyludzkich zachowań. Zarówno stereotypowe postrzeganie innych, jak i uprzedzenia względem nich utrudniają nawiązanie i rozwijanie konstruktywnych relacji, w szczególności w społeczeństwie wielokulturowym, gdzie współistnienie przedstawicieli różnych narodów, grup etnicznych i wyznaniowych stanowi podstawę codziennego funkcjonowania.

Dlatego też sposoby zapobiegania powstawaniu oraz redukowania już istniejących stereotypów i uprzedzeń stały się przedmiotem zainteresowania przedstawicieli nauk społecznych [Nelson, 2013]. Początkowo założono, 
że podstawą kształtowania się uprzedzeń jest strach i niewiedza [Allport, 1954]. Tak więc, jak mówi hipoteza kontaktu [Allport, 1954], wyeliminowanie tych dwóch czynników w wyniku bezpośredniej styczności z obiektami uprzedzeń powinno przyczynić się także do redukcji lub całkowitego zniwelowania negatywnej postawy wobec nich. Kontakt taki powinien otrzymać wyraźne wsparcie osób stanowiących autorytety dla uczestników spotkania, którym należy również wyznaczyć wspólny cel, ważny dla obu stron, którego realizacja byłaby bezwzględnie uzależniona od wzajemnej współpracy i wykorzystania wiedzy wszystkich grup biorących udział w realizacji zadania. W praktyce okazało się jednak [Nelson, 2013], że aby zapewnić skuteczność spotkań, konieczne jest dodanie kolejnych warunków. Mówią one, że kontakt zwalczający uprzedzenia powinien być nie jednostkowy ale częsty i obejmować wielu przedstawicieli wybranej grupy, cechować się nieformalną, przyjacielską atmosferą oraz być wsparty społecznymi normami zakładającymi równość między jednostkami i zbiorowościami reprezentującymi różne grupy społeczne. Należy również w taki sposób dobrać uczestników spotkania, aby reprezentowali oni porównywalny status społeczny, gdyż jego duża dysproporcja może zaburzyć możliwość swobodnego nawiązania i pogłębiania relacji [Pettigrew, 1998]. Do pierwszych eksperymentów testujących skuteczność hipotezy kontaktu należał eksperyment Sheriffa przeprowadzony na grupie młodzieży w Robbers Cave State Park, Oklahoma [Sherif i in., 2016], który udowodnił że odpowiednia aranżacja kontaktu między osobami o początkowo neutralnym stosunku do siebie może doprowadzić do wytworzenia wzajemnych uprzedzeń. Następnie udowodniono, że dalsze projektowanie spotkań pozwala - w optymalnych warunkach - na usunięcie powstałych negatywnych ustosunkowań lub nawet do nawiązania przyjaźni i wytworzenia wzajemnych pozytywnych i przyjacielskich relacji między stronami konfliktu [Sherif, 1958].

Jak wobec tego przygotować edukacyjne przestrzenie umożliwiające kontakt $\mathrm{z}$ innymi i jak wspierać międzykulturowe komunikowanie się pomimo różnic? Odpowiedź na powyższe pytanie nie jest łatwa z uwagi na brak spójności w zakresie hipotezy kontaktu międzykulturowego, ale też - o czym wspomina Paweł Boski - ze względu na brak orientacji kulturowej, brak przedsięwzięć praktycznych podporządkowanych zmianom relacji międzykulturowych [Dąbrowa, Markowska-Manista, 2014] oraz z uwagi na znaczne zróżnicowanie przestrzeni komunikacji międzykulturowej. Krystyna Błeszyńska wyodrębnia trzy kluczowe dla komunikacji międzykulturowej 
przestrzenie, które konstruują odmienne dla procesów komunikacyjnych warunki [Błeszyńska, 2013: 5]. Pierwsza z nich jest w miarę jednolita kulturowo i odnosi się do różnic pomiędzy kulturą gospodarzy a kulturą przybyszy. Druga zaś, to przestrzeń w miarę homogeniczna kulturowo, usytuowana w obrębie nadrzędnej wobec niej przestrzeni zewnętrznej o odmiennych cechach kulturowych. Zaś trzecia przestrzeń charakteryzuje się zróżnicowaną kompozycją kulturowo-etniczną wszystkich lub większości aktorów [Błeszyńska, 2013: 5]. Wszystkie powyższe przestrzenie mogą zarówno wyzwalać jak i hamować proces komunikacji międzykulturowej.

Polska przez stulecia była krajem różnorodnym etnicznie i wyznaniowo. Mimo pojawiających się nieporozumień oraz drobnych i większych konfliktów, różne grupy współżyły ze sobą starając się wykorzystać różnorodność dla wzajemnego wsparcia i wspólnego rozwoju. Po tym okresie, w wyniku wydarzeń drugiej wojny światowej, Polska na długi okres stała się państwem monokulturowym i monoetnicznym. A także później, wokresie komunizmu, państwem ograniczającym swoim obywatelom możliwość styczności z przedstawicielami innych krajów poprzez ścisłe monitorowanie i ograniczanie możliwości zarówno wyjazdu jak i przekroczenia granic Polski przez cudzoziemców. Według pierwszego powszechnego spisu ludności dokonanego w 1921 roku (GUS'), ludność Polski stanowili w jednej trzeciej przedstawiciele innych narodowości. Według spisu powszechnego z roku 2011 (GUS ${ }^{2}$ ), przedstawiciele innych narodowości stanowili już tylko 7\% społeczeństwa.

Po wejściu Polski do Unii Europejskiej w 2003 roku rozpoczął się intensywny rozwój procesów integracyjnych i realizacja wielostronnych projektów międzynarodowych. Jednym z filarów europejskiego umiędzynarodowienia jest pakiet programów ukierunkowanych na wychowanie młodego pokolenia obywateli do życia we wspólnocie europejskiej, aktywnego uczestnictwa w życiu społecznym oraz szacunku dla różnorodności [Fatyga, 2004]. W programach tych zawarte są następujące propozycje oparte o kontakt i komunikację międzykulturową: wizyty studyjne, wymiany uczniów i nauczycieli, wizyty zagraniczne kadry akademickiej, wspólne, międzynarodowe badania naukowe, wymiany międzykulturowe, szkolenia językowe i zawo-

\footnotetext{
1 http://web.archive.org/web/20130617162348/http://www.stat.gov.pl:80/gus/5840_5620_ PLK_HTML.htm [16.07.2016].

2 http://stat.gov.pl/cps/rde/xbcr/gus/lu_nps2011_wyniki_nsp2011_22032012.pdf [16.07.2016].
} 
dowe dla młodych dorosłych (osoby w wieku 20-25 lat), czyli subkategorii grupy społeczeństwa określanej jako młodzież (osoby w wieku 11-25 lat) [Fatyga, 2004]. Mimo iż tematyka takich projektów obejmuje szerokie spektrum społecznych i kulturowych zagadnień, ich podstawowym założeniem jest nabycie przez uczestników kompetencji międzykulturowych, „oswojenia się" z różnorodnością kultur jakie wniosły do Wspólnoty Europejskiej poszczególne kraje członkowskie, poznanie się, nawiązanie bliższych kontaktów i uczenie się współistnienia oraz współpracy dla obopólnej korzyści. Powyższa programowa inicjatywa UE pociągnęła za sobą szereg propozycji przygotowanych przez władze lokalne i struktury rządowe poszczególnych państw członkowskich, wspierające kontakty międzynarodowe i międzykulturowe w różnych obszarach - ze szczególnym naciskiem na edukację i wymianę dobrych praktyk, sztukę oraz propagowanie dziedzictwa kulturowego i historycznego na kontynencie europejskim. Szerokim zainteresowaniem - szczególnie przy wsparciu władz lokalnych - cieszą się też pomysły spotkań ekumenicznych, ukierunkowanych na nawiązanie i rozwój dialogu międzyreligijnego oraz wskazanie wyznawcom poszczególnych religii potrzeby wzajemnego szacunku i porozumienia. Aby jednak takie spotkania przyniosły zamierzony efekt, spełnionych musi zostać szereg warunków zawartych w hipotezie kontaktu międzygrupowego w warunkach międzykulturowości.

\section{Kontakt międzykulturowy w praktyce}

Inicjowanie kontaktu międzygrupowego w realizacji edukacyjnych projektów międzykulturowych rozpoczyna się od nawiązania relacji pomiędzy organizacjami, które będą realizowały dany projekt. Z perspektywy organizacji pozarządowej wybór partnera do konkretnego projektu nie jest kwestią prostą. Wymaga przede wszystkim sprecyzowania oczekiwań i stworzenia profilu organizacji, która będzie wpisywała się w tematykę i zakres planowanych działań. Kolejnym wyzwaniem jest znalezienie potencjalnych partnerów i wybór - spośród nich - organizacji, mających jak największy potencjał do konstruktywnej współpracy. Po dokonaniu selekcji następuje pierwszy bezpośredni kontakt międzykulturowy. Również na tym etapie mogą pojawić się bariery w komunikacji i nieporozumienia związane z różnicami kulturowymi i funkcjonowaniem rozmówców w odmiennych skryptach kulturowych i zróżnicowanych ramach zachowań społecznych. Przy- 
kładowo, organizacje z niektórych krajów niekiedy w ogóle nie odpisują na wiadomości przesyłane pocztą elektroniczną od nieznanych, niepoleconych wcześniej nadawców. W innych miejscach natomiast korespondencja elektroniczna jest jedną z podstawowych i najbardziej powszechnych form przekazywania informacji i nawiązywania kontaktu. Dodać należy, że również czas odpowiedzi, podejmowania decyzji, wypełniania dokumentów aplikacyjnych i programowych przez organizacje na przykład z obszarów śródziemnomorskich czy Bliskiego Wschodu wydaje się być znacznie wydłużony w porównaniu z oczekiwaniami mieszkańców Europy Środkowej czy Północnej. Wiedząc o tym, można przygotować się na dłuższe oczekiwanie na zwrot podpisanych umów czy deklaracji i adekwatnie do tego zaplanować terminy implementacji działań w harmonogramie. Można też rozważyć realizację tych elementów podczas spotkań indywidualnych (koordynatorów), co jest bardziej efektywne i pozwala uniknąć zbędnego stresu oraz nieporozumień międzykulturowych, choć ze względów finansowych ${ }^{3}$ czę- $^{-}$ sto pozostaje niemożliwe do realizacji w praktyce. Ustalenie zakresu realizowanego programu między koordynatorami z poszczególnych krajów także wymaga wielu starań. Pierwszym z wysiłków, jakie stoją przed organizatorami jest ustalenie wspólnego języka tak, aby terminologia jaką posługują się obie strony dialogu była taka sama, a nie rozbieżna. Niezwykle ważne jest również ustalenie priorytetów i wymagań programu jeśli są narzucone przez instytucję zewnętrzną finansującą realizowane działania (na przykład Unia Europejska, ministerstwo danego kraju). Zdając sobie sprawę z pojawiających się licznych wyzwań dla prawidłowej realizacji projektów, których celem jest nawiązanie kontaktu międzykulturowego, specjaliści pracujący w strukturach Unii Europejskiej jak również instytucje rządowe, opracowują i publikują liczne skrypty wspomagające prowadzenie tego rodzaju działań i szkoleń ${ }^{4}$.

Szczególnie istotnym zagadnieniem wpisującym się w międzynarodową współpracę projektową są w ostatnich latach kontakty polsko-izraelskie i polsko-żydowskie. Polska i Izrael od momentu nawiązania oficjalnych stosunków dyplomatycznych w roku 1990 deklarują potrzebę poszerzania działań umożliwiających młodzieży z obu krajów wzajemne poznanie się i nawiązanie dia-

\footnotetext{
3 W większości programów koszt wizyt przedprojektowych związanych z przygotowaniem projektów nie jest finansowany.

4 https://www.salto-youth.net/tools/toolbox/ [16.07.2016].
} 
logu [Umowa o Wymianie Młodzieży, 20115]. Wymiana młodzieży w przywołanym dokumencie rozumiana jest bardzo szeroko, obejmując swoim zakresem działania takie jak seminaria, konferencje i spotkania popularyzujące wiedzę historyczną, dorobek naukowy i kulturalny obu krajów, wspólną opiekę nad zabytkami i dziełami sztuki, działania na rzecz nawiązania dialogu i rozwoju kontaktu między młodym pokoleniem Polaków i Izraelczyków oraz współpracę między organizacjami i stowarzyszeniami młodzieżowymi. Wymienionymi przez ustawodawcę beneficjentami mogą być zarówno uczniowie i studenci, jak również młodzi pracownicy naukowi, członkowie organizacji młodzieżowych, przywódcy polityczni oraz kadra organizacji pracujących z młodzieżą. Kluczowym elementem wymiany młodzieżowej jest umożliwienie nawiązania pogłębionego kontaktu grupie ludzi, których łączy podobny wiek, zainteresowania, wspólne działanie i cele. Mimo to, nadal zdecydowana większość młodzieży izraelskiej odwiedzającej Polskę w ostatniej dekadzie przyjeżdża tu w ramach wizyt edukacyjnych ${ }^{6}$ realizowanych przez izraelskie licea, nadzorowanych przez izraelskie Ministerstwo Edukacji [więcej: Szuchta, 2007: 12-14; Winiewski, Halska, Bulska, 2015: 55-57]. Program wizyt studyjnych skoncentrowany jest jednak przede wszystkim na jednym aspekcie: pogłębieniu wiedzy o martyrologii żydowskiej, w szczególności na przybliżeniu w bardzo wyrazisty sposób doświadczenia Zagłady, jakie przypadło w udziale społeczności żydowskiej zamieszkującej Europę wokresie drugiej wojny światowej. Podczas tych wizyt młodzież izraelska odwiedza głównie obozy zagłady oraz miejsca upamiętniające zamordowanych Żydów. Natomiast kontakt - nie tylko z Polakami, ale też polską mniejszością żydowską jest bardzo ograniczony, a niekiedy nie bierze się pod uwagę możliwości i potrzeby spotkania oraz obopólnej wartości międzykulturowego komunikowania. Jeśli w ogóle dochodzi do kontaktu to są to kilkugodzinne spotkania odbywające się $\mathrm{w}$ atmosferze pośpiechu i nierzadko niechęci ze strony nauczycieli izraelskich. Wizyty te zwykle odbywają się jesienią, kiedy pogoda w Polsce jest deszczowa, pochmurna i chłodna, co ma potęgować doświadczenia odwiedzających. Spotkania te, realizowane w formalnej atmosferze nie pozostawiają przestrzeni na nawiązanie przyjacielskich, bezpośrednich relacji. Ze względu na ograniczony czas nie są rozpoczynane od właściwej inte-

\footnotetext{
5 https://d1dmfej9n5lgmh.cloudfront.net/msport/article_attachments/attachments/10735/ original/Izrael_program.pdf?1334722066 [16.07.2016].

6 http://embassies.gov.il/warsaw/Relations/ProjectActivities/Documents/HiddenOpportunities.pdf [21.07.2016].
} 
gracji grupy ani pokazania korzyści, jakie płyną dla uczestników z aktywnego angażowania się w proponowane działania. Wydźwięk tych ostatnich, skoncentrowany na przeszłości i dyskusji o wzajemnych oskarżeniach nie pozostawia przyjemnych wspomnień. Zdarza się również, że żadna ze stron nie jest merytorycznie przygotowana na dyskusję, jakiej prowadzenia się od niej oczekuje. Jak pokazują badania postaw wobec Polski i Polaków [Zakrzewska, Żochowska, 2013], tego rodzaju działania potęgują niechęć młodych Izraelczyków wobec państwa polskiego i jego obywateli, wzmacniając wzajemne uprzedzenia i stereotypy.

Aby stworzyć przeciwwagę dla tych wyjazdów, polskie organizacje pozarządowe zaproponowały szereg inicjatyw realizujących założenia wymian młodzieżowych, przygotowanych przez profesjonalnych edukatorów i trenerów w sposób zapewniający możliwość nawiązania pogłębionego kontaktu pomiędzy uczestnikami. Jedną z nich były projekty „Żywy Most Polska-Izrael” oraz „Leadership Program - Seminars for Israeli Educators in Poland”, realizowane w latach 2010-2015 przez organizacje pozarządowe z Polski i Izraela we współpracy z wybranymi placówkami edukacyjnymi i ośrodkami akademickimi z obu krajów. Do podstawowych założeń projektów należała realizacja 7-8 dniowych wizyt w pierwszym wypadku wzajemnych, w drugim z wymienionych projektów wizyt studyjnych w Polsce dla młodzieży lub młodych dorosłych. Grupy liczyły 16-20 osób, równolicznych pod względem narodowości i przy zachowaniu w miarę możliwości równego udziału procentowego dziewcząt i chłopców. Celem było stworzenie poprzez wspólną naukę i doświadczenie przestrzeni do budowania dialogu, wzajemnego zrozumienia oraz długofalowych przyjaźni między obywatelami Polski i Izraela. Tematyka spotkań, w przeciwieństwie do podobnych projektów realizowanych przez inne polskie organizacje pozarządowe, nie była skoncentrowana na Holokauście ani negocjowaniu wspólnej wersji historii; jakkolwiek był to jeden z wielu tematów poruszanych podczas warsztatów i dyskusji. Pierwszym etapem, jakiego osiągnięcie w ramach spotkań założyli organizatorzy, było poznanie się młodzieży w kontekście wyzwań życia we współczesnym świecie, przełamanie barier językowych, nawiązanie relacji i wytworzenie poczucia bezpieczeństwa w grupie. A także pokazanie współczesnej Polski, jako rozwijającego się kraju europejskiego wraz z całą dostępną w niej ofertą edukacji i rozwoju skierowaną do młodych ludzi. Młodzież z Polski i Izraela podejmowała wspólny wysiłek podczas szkoleń i treningów związanych z wybranymi przez nich kierunkami studiów czy też wykonywanym zawodem. Dopiero po przej- 
ściu tej fazy w ciągu dwóch-trzech pierwszych dni, wprowadzano tematykę drugiej wojny światowej w taki sposób, aby przed podjęciem dyskusji wyposażyć obie strony kontaktu w rzetelną, jak najbardziej obiektywną, wiedzę o sytuacji zarówno Polaków jak i Żydów oraz uświadomić szerszy kontekst społeczno-polityczny wydarzeń. W tym punkcie wielu uczestników przeżywało ogromne rozterki, często po raz pierwszy uświadamiając sobie złożoność tego okresu historii. Pojawiające się w następstwie dyskusje były niezwykle emocjonalne, jednak, również $\mathrm{w}$ większości przypadków, prowadzące do konstruktywnych idei. Towarzyszyły im komentarze uczestników mówiących, że tego rodzaju wizyty powinny być obligatoryjne dla wszystkich uczniów z Polski i Izraela oraz deklaracje dalszego zaangażowania w pogłębianie i przekazywanie zdobytej wiedzy kolejnym osobom. O ich słowności świadczyć może fakt, iż po pierwszej edycji pilotażowej projektu, do której rekrutacja uczestników była trudnym i czasochłonnym zadaniem, większość kolejnych grup zgłaszała się sama w większej liczbie niż przewidywały możliwości projektu. Można więc wnioskować, że udział w zrealizowanych działaniach zapadł głęboko w pamięć i świadomość uczestników.

Osiągane rezultaty i efektywność spotkań były mierzone za pomocą kwestionariuszy uzupełnianych przez uczestników przed i po udziale w seminariach. Podczas seminariów przeprowadzano także ewaluację ustną, która składała się z trzech etapów:

1) zdefiniowania oczekiwań uczestników na początku projektu,

2) regularnych dyskusji podczas trwania działań projektowych,

3) spotkania podsumowującego po jego zakończeniu.

Podczas trwania projektów zrealizowane zostało również badanie poziomu wzajemnych uprzedzeń między Polakami a Izraelczykami, którzy uczestniczyli w projekcie oraz grupą kontrolną, która nigdy nie miała kontaktu z przedstawicielami drugiego kraju. Wykorzystano w nim Skalę Dystansu Społecznego (Bogardus), Termometr Uczuć (Bilewicz, Jaworska) oraz Skalę Postrzeganego Podobieństwa Grupy Obcej do Ja (Bilewicz, Jaworska) [więcej: Zakrzewska, 2013]. Pokazało ono istotnie niższy poziom wzajemnego postulowanego dystansu społecznego, większe poczucie podobieństwa i bardziej ciepłe uczucia w grupach, które miały ze sobą kontakt niż między osobami, które w tym kontakcie nie miały okazji uczestniczyć.

Po pierwszych doświadczeniach wyraźnie zaobserwowano, że kiedy grupy mieszkały wspólnie przez cały czas trwania projektu (tydzień w Polsce i tydzień w Izraelu), odnotowano zdecydowanie większą zmianę wzajemnych 
postaw niż gdy uczestnicy z kraju, w którym odbywało się seminarium mieszkali w domach rodzinnych, a goście w hotelu. Drugim znaczącym czynnikiem była wspólna realizacja kilkugodzinnych działań wolontariackich na rzecz lokalnej społeczności. Niezależnie od rodzaju działania (na przykład przeprowadzenie zabaw ruchowych dla dzieci z domu dziecka, spotkanie ze starszymi osobami whospicjum, malowanie lokalnego ośrodka kultury, sprzątanie parku i plaży), miały one pozytywny wpływ na wzajemne relacje między uczestnikami. Również lepsze rezultaty integracji odnotowano w grupach, których uczestnicy zostali dobrani pod kątem podobnych zainteresowań (na przykład kierunek studiów, hobby). Niezwykle ważny dla relacji w grupie był też równy wkład uczestników z obu krajów w udział w projekcie (finansowy, rzeczowy lub wolontariacki) oraz wspólne z uczestnikami przygotowanie programu i przydzielenie im zadań do realizacji w trakcie projektu. W sytuacji, kiedy każda z osób była odpowiedzialna za wybrany fragment warsztatów lub wycieczek, poziom zaangażowania studentów i ich końcowe zadowolenie z udziału były w zauważalnym stopniu większe. Osoby bardziej zaangażowane osobiście we wsparcie projektu były skupione na tym, co one mogą wnieść, aby podnieść poziom wspólnych działań. Natomiast uczestnicy niemający wyznaczonych ról wykazywali raczej tendencje do roszczeniowości wobec organizatorów, wyszukiwania uchybień i wskazywania błędów. Ogromnie istotny okazał się także kontakt między organizatorami z poszczególnych organizacji. Kiedy relacje między opiekunami przebiegały płynnie, także członkowie grup bardziej efektywnie ze sobą współpracowali. Natomiast jeśli pojawiały się nieporozumienia na poziomie osób decyzyjnych, niesnaski przenosiły się także na relacje na poziomie uczestników nawet jeśli nie byli oni w pełni świadomi źródła pojawiających się trudności.

Podobne doświadczenia pozytywnego wpływu kontaktu zaaranżowanego w sposób zgodny z zaleceniami hipotezy kontaktu na relacje polskoizraelskie zaobserwowano w wyniku działań Izraelsko-Polskiego Forum Dialogu [Kuleta-Hulboj, 2008] oraz warsztatów realizowanych przez Forum Dialogu Między Narodami [Bilewicz, 2006] choć spotkania te charakteryzowała odmienna struktura. Również ich tematyka zawierała więcej elementów dialogu historycznego i nastawienia na zrozumienie motywacji działań uczestników wydarzeń historycznych, z koncentracją na sytuacji mniejszości Żydowskiej podczas Zagłady i reakcji Polaków na nią.

W prezentowanych projektach „Żywy Most-Polska/Izrael” oraz „Leadership Program - Seminars for Israeli Educators in Poland” główny nacisk 
położony został na obecne możliwości rozwoju relacji i współpracy, wzajemnego poznania się i budowania przyszłości, choć nie unikano w nim bolesnych tematów takich, jak Holokaust. Nie był on jednak centralnym elementem dialogu, a jedynie jednym z poruszanych tematów. Zwracano również uwagę na zachowanie równowagi - jeśli organizowane były ceremonie upamiętniające ofiary żydowskie, dbano o to, aby odbyła się też analogiczna uroczystość upamiętniająca na przykład polskich Sprawiedliwych Wśród Narodów Świata lub uczestników Powstania Warszawskiego. Poświęcano też uwagę pokazaniu elementów współpracy między oboma grupami tam, gdzie takie sytuacje miały miejsce.

O różnicy w doświadczeniu zaprezentowanych rodzajów kontaktu między uczestnikami spotkań międzykulturowych, z jednej strony wizyt martyrologicznych młodzieży izraelskiej w Polsce, a z drugiej spotkań młodzieży świadczyć mogą wypowiedzi osób, które brały w nich udział․ Jedna $\mathrm{z}$ respondentek wskazała jak poprzez kontakt i możliwość komunikacji międzykulturowej zmieniła swoje postrzeganie Polski i Polaków:

przed seminarium myślałam, że Polska jest krajem Holokaustu, że wszystko w Polsce jest smutne i złe. Myślałam, że krajobraz jest depresyjny i przytłaczający, dający nieprzyjemne uczucia. Seminarium zmieniło moje nastawienie i odkryłam, że Polska to coś więcej niż te wszystkie rzeczy. Że Polacy są miłymi, ciepłymi ludźmi i jeśli wiesz jak rozmawiać i masz otwarty umysł, możesz z sukcesem nawiązać pozytywne interakcje. Myślę, że Polacy pomogli nam bardzo zmienić nasze nastawienie przez to, że byli tak przyjaźni i otwarci wobec nas od samego początku (1SKI2014).

Inna zwróciła uwagę na fragmentaryczną, ukierunkowaną na Holokaust wiedzę historyczną o Polsce:

przed seminarium Polska była dla mnie tylko miejscem Holokaustu. Nie wiedziałam nic o tym kraju i jego mieszkańcach. Nie pamiętałam dokładnie jej historii. Pamiętałam tylko, że Rosjanie oswobodzili Polskę od Niemców, ale nigdy nie wiedziałam, że zostali tutaj. Właściwie, nie było dla mnie nigdy istotne żeby cokol-

\footnotetext{
$7 \quad$ Fragmenty wywiadów przeprowadzonych wśród polskich i izraelskich uczestników w ramach projektu „Leadership Program - Seminars for Israeli Educators in Poland” w roku 2014, Warszawa.

8 Zastosowałyśmy następujący sposób kodowania wypowiedzi respondentek i respondentów: 1,2,3... numer porządkowy wywiadu, $\mathrm{S}$ - student/studentka, $\mathrm{K}$ - kobieta/M - mężczyzna, I - Izrael, Pl - Polska, rok przeprowadzenia wywiadu.
} 
wiek o tym wiedzieć. Byłam w Polsce w liceum. To była podróż z jednym celem: uczyć się o Żydowskim Holokauście (3SKI2014).

Kolejna z rozmówczyń potwierdziła, jak ważny w przełamywaniu barier i niwelowaniu uprzedzeń jest bezpośredni kontakt:

zawsze żywiłam uprzedzenia wobec Polaków, ponieważ korzenie mojej babci są z Polski, a ona jest typową polską starą kobietą. Podczas jednej z rozmów powiedziano nam, że Polacy są zimnymi ludźmi, nie powinniśmy zadawać im osobistych pytań na początku i powinniśmy być bardzo ostrożni między nimi. Ale moje oczekiwania nie sprawdziły się w rzeczywistości. Odkryłam bardzo ciepłych ludzi (mam na myśli młode pokolenie), którzy byli bardzo zainteresowani naszą kulturą. Oni są bardzo podobni do nas, podejrzewam że ludzie to ludzie, niezależnie gdzie mieszkają i w jakiej kulturze się wychowali (2SKI2014).

$\mathrm{Na}$ istotną rolę kontaktu międzykulturowego wskazali również respondenci z Polski, uczestnicy wspomnianych projektów. Jedna z Polek - odnosząc się w wywiadzie do kontaktów międzykulturowych i porozumiewania pomiędzy Izraelczykami i Polakami podkreśliła, że:

najważniejszym punktem programu było poznanie studentów z Izraela. Przez kilka dni mogliśmy mieszkać w jednym miejscu i dogadywać się z nieznajomymi osobami w obcym dla nas wszystkich języku angielskim. Myślę, że się udało. To było niesamowite - wspólne porozumienie. Nauczyłam się rezygnacji z oceniania ludzi, zrozumiałam że istotne jest by najpierw kogoś poznać. Nie ma barier jeżeli ty sam ich nie stwarzasz. Nie miało dla mnie znaczenia to skąd przyjeżdżają studenci. Nie miało to dla mnie znaczenia, czy są tej samej religii. Cieszę się, że poznałam nowych wspaniałych przyjaciół (4 SKPl2014).

Kolejny respondent $\mathrm{z}$ Polski zwrócił uwagę na rolę integracji międzynarodowej poprzez uczestnictwo $\mathrm{w}$ działaniach $\mathrm{z}$ obszaru edukacji nieformalnej oraz wspólne spędzanie czasu wolnego:

najważniejszym punktem programu była możliwość integracji ze studentami z Jerozolimy, bo jak inaczej budować most jeśli nie poprzez łamanie barier i stereotypów związanych z naszymi krajami, jeśli nie poprzez poznanie wzajemne i wspólne spędzanie czasu? Oczywiście ważna jest także wspólna przeszłość, ale według mnie jest ona na drugim miejscu. Nie podoba mi się nastawienie, że skoro przyjeżdżają osoby z Izraela to koniecznie trzeba je zabrać do wszystkich możliwych miejsc związanych z przeszłością, wojną i Holokaustem. Tak naprawdę przecież przyjeżdżają do Polski by zobaczyć prawdziwą, dzisiejszą Warszawę [...] (5SMPl2014). 
Inna Polka w swoje wypowiedzi zwróciła uwagę na wartość wzajemnej komunikacji, wspólnych działań i bycia razem:

\begin{abstract}
dla mnie samo zderzenie z inną kulturą, jej poznanie i zrozumienie było bardzo pozytywne. Wspólne zajęcia które prowadziliśmy w przedszkolach w Lublinie i Warszawie były okazją do tego, by poznać inne sposoby pracy z dziećmi. To rozwija wyobraźnię i pomaga szukać własnych pomysłów metodycznych. Program był też okazją by ćwiczyć język angielski, poznawać ludzi pozytywnie myślących o innych. Jestem zaskoczona, że grupa izraelska jest niesamowicie otwarta na ludzi. To zmieniło moje myślenie o innych. Czasami program naszych zajęć był zbyt napięty, ale rozumiem, że było mało czasu. Nic bym nie zmieniła w programie, może tylko liczbę spotkań danego dnia. Gdyby te aktywności trwały krócej umysł nie byłby tak przeciążony pracą i trudną wiedzą dotyczącą wspólnej historii (6SKPl2014).
\end{abstract}

W niektórych z wypowiedzi można też zauważyć odwołanie do pokazania różnych punktów widzenia i narracji historycznych oraz poznania faktów, bez których ciężko jest w pełni zrozumieć sytuację drugiej strony:

myślę że wizyta tego samego dnia w Muzeum Powstania Warszawskiego i w Muzeum Historii Żydów Polskich była bardzo ważna. Mimo że był to niesamowicie wyczerpujący dzień (to było zbyt dużo informacji bez wystarczającej ilości czasu żeby wszystko naprawdę zrozumieć), myślę jednak, że było to konieczne. Poczułam jakbym właściwie nie wiedziała wystarczająco o polskiej stronie, która przeszła przez tą samą wojnę. Wszystko czego byłam uczona podczas lekcji historii to była nasza strona (historia Żydów). A ta wizyta sprawiła, że spojrzałam na ten fragment historii dużo szerzej. To było także ważne żeby pójść do tych muzeów razem z Polakami i dzielić się swoimi spostrzeżeniami i uczuciami podczas wizyty (7SKI2014).

W kontekście wspomnianych projektów warto zwrócić uwagę na istotność wspólnych działań - nie tylko dla ludzi biorących w nich udział, ale również w szerszym edukacyjnym wymiarze związanym $\mathrm{z}$ oddziaływaniem na środowisko, przestrzeń i miejsce, w których odbywa się dany projekt.

\title{
Zakończenie
}

W tekście podjęłyśmy próbę wskazania możliwości zastosowania teorii kontaktu w praktyce odnoszącej się do międzykulturowych projektów edukacyjnych i społecznych. Jak wskazują doświadczenia z realizacji opisanych projektów, kontakt w grupach kulturowo zróżnicowanych, realizujących 
określone zadania i cele, umożliwia niwelowanie i redukcję narodowych oraz etnicznych stereotypów i uprzedzeń.

Okazję do doświadczania inności i odmienności stwarza niewątpliwie możliwość bezpośredniego spotkania i doświadczania kulturowej różnorodności w przestrzeni edukacji formalnej i pozaformalnej, w środowisku lokalnym, bądź poza krajem pochodzenia, tak jak starałyśmy się uwypuklić na podstawie polsko-izraelskich projektów współpracy. Tego typu możliwości oferują również projekty realizowane w ramach współpracy szkół z organizacjami pozarządowymi, instytucjami oświatowymi i placówkami kulturalnymi, w szczególności w obszarze działań międzynarodowych i/lub międzykulturowych. Kolejny, istotny dział stanowią międzynarodowe wymiany szkolne i wizyty studyjne ze szkołami partnerskimi oraz szereg międzynarodowych programów nakierowanych na współpracę i dialog w wymiarze edukacji szkolnej. Edukatorzy, nauczyciele i ich uczniowie przygotowując i realizując tego typu inicjatywy uczą się współpracy w międzynarodowym zespole, doskonalą swoje kompetencje językowe, mają możliwość podniesienia poziomu wiedzy dotyczącej innych kultur oraz praktycznego uczenia się współpracy w zróżnicowanych grupach i komunikacji z osobami o innym kontekście kulturowym. Konfrontacja z różnorodnością we wspomnianych obszarach funkcjonowania pozwala nabyć bogate doświadczenia edukacyjne i przygotować do pełnego uczestnictwa w wielokulturowym społeczeństwie. Odpowiednie tworzenie i modelowanie własnej kultury na poziomie jednostkowym pomaga zagwarantować nabywanie szacunku dla swoich i innych, co ma niebagatelne znaczenie dla kreowania postaw zrozumienia i dialogu w czasach narastającego radykalizmu i ksenofobii.

\section{BIBLIOGRAFIA}

Allport G., (1954). The Nature of Prejudice, Addison-Wesley Publishing Company Massachusetts, California, London, Amsterdam, Ontario, Sydney

Aronson E., Wilson T. D., Akert R. M. (1997). Uprzedzenia. Przyczyny i środki zaradcze, (w:) Psychologia Społeczna. Serce i umyst, Poznań

Bem M., (2013), Modele kompetencji międzykulturowych, (w:) J. Muszyńska, W. Danielewicz, T. Bajkowski (red.), Kompetencje międzykulturowe jako kapitat społeczności wielokulturowych, Warszawa

Bilewicz M., (2006), Kiedy kontakt osłabia uprzedzenia? Kategoryzacje społeczne i temporalne jako warunki skuteczności kontaktu międzygrupowego, „Psychologia Społeczna”, t. 1(02)

Błeszyńska K., (2013), Komunikacja międzykulturowa jako negocjowanie znaczeń, „Pogranicze. Studia Społeczne", t. XXI 
Dąbrowa E., Markowska-Manista U., (2014), Contact theory in multicultural school praxis, (w:) I. Nowosad (red.), International Forum for Education, nr 1(7) School Quality and Culture, Toruń

Fatyga B., (2004), Słownik antropologii i socjologii kultury, Warszawa

Kuleta-Hulboj M., (2008), Spotkanie z Innym. Czy polsko-izraelska wymiana młodzieży sprzyja nawiązaniu relacji dialogicznej? „Pedagogika Społeczna”, t. 4

Nikitorowicz J., (2013), Kompetencje do komunikacji międzykulturowej w aspekcie tradycyjnej wielokulturowości regionu aspekcie procesów migracyjnych, (w:) J. Nikitorowicz, A. Sadowski, M. Sobecki (red.), „Pogranicze. Studia Społeczne”, t. XXI

Nelson T. D., (2013), Przeciwdziałanie uprzedzeniom, (w:) Psychologia uprzedzeń, Gdańsk

Nelson T. D., (2013), Wprowadzenie w tematykę stereotypizacji i uprzedzeń. Definicje uprzedzeń, (w:) Psychologia uprzedzeń, Gdańsk

Pettigrew T. F., (1998), Intergroup Contact Theory. „Annual Review of Psychology”, t. 49

Sherif M., (1958), Superordinate goals in the Reduction of Intergroup Contact. „The American Journal of Sociology", t. 63, nr 4

Sherif M., Harvey O. J., White B. J., Hood W. R., Sherif C. W., Intergroup Conflict and Cooperation: The Robbers Cave Experiment. 1954-1961, Classics in the History of Psychology, An internet resource developed by Christopher D. Green York University, Toronto, Ontario, http://psychclassics.yorku.ca/Sherif/ [16.07.2016]

Szuchta R., (2007), Podróż do przeszłości. Podróże studyjne młodzieży izraelskiej do Polski, „Przegląd Edukacyjny”

Winiewski M., Haska A., Bulska D., (2015), Krytyka państwa Izrael a antysemityzm, (w:) A. Stefaniak, M. Bilewicz, M. Winiewski (red.), Uprzedzenia w Polsce, Warszawa

Zakrzewska D., (2013), Gotowość do agresji i wzajemne uprzedzenia wśród młodzieży polskiej i żydowskiej. Międzynarodowe studia porównawcze polsko-izraelskie. Praca magisterska przygotowana pod kierunkiem prof. dr. hab. A. Frączka, Akademia Pedagogiki Specjalnej, Warszawa (maszynopis)

Zakrzewska D., Żochowska A., (2013), Mutual prejudice among Polish and Jewish adolescents. Research announcement, materiał konferencyjny, IV Tajfel Seminar. History, reconcilliation and intergroup relations, Warszawa

\section{ŹRÓDŁA INTERNETOWE}

http://www.uniaeuropejska.info.pl/polska-w-unii-europejskiej [16.07.2016]

http://stat.gov.pl/spisy-powszechne/nsp-2011/ [16.07.2016]

http://web.archive.org/web/20130617162348/http://www.stat.gov.pl:80/gus/5840_5620_ PLK_HTML.htm [16.07.2016]

https:/www.salto-youth.net/tools/toolbox/ [16.07.2016]

https://d1dmfej9n5lgmh.cloudfront.net/msport/article_attachments/attachments/10735/ original/Izrael_program.pdf?1334722066 [16.07.2016]

http://embassies.gov.il/warsaw/Relations/ProjectActivities/Documents/HiddenOpportunities.pdf [21.07.2016] 


\section{Between the theory and praxis of intercultural contact}

The text draws attention to the theory and practice of intercultural contact, constituting the basis of the communal functioning of communities, groups and individuals. By referring to interactionist concepts and praxis, we attempt to present the realities of conducting intercultural (Polish-Israeli) youth meetings. The meetings allow to increase the chance of achieving positive results in the area of reducing mutual stereotypes and prejudice. The text attempts to indicate the possibilities of applying the theory of intercultural contact in praxis related to international Polish-Israeli projects which conform to the framework of intercultural education.

KEYWORDS: intercultural contact, intercultural communication, youth projects, intercultural education, stereotypes and prejudices. 